\title{
Traffic volume Analysis of Newly Developing semi-urban Road
}

\author{
$S$. Venkatcharyulu ${ }^{1}, V$. Mallikarjunareddy ${ }^{2}$, \\ ${ }^{1}$ Assistant Professor Gokaraju RangaRaju Institute of Engineering and Technology Hyderabad, India and \\ Research scholar, Department of Civil Engineering, JNTUHCEH, Kukatpally, Hyderabad, India \\ ${ }^{2}$ Professor \& Head of civil Engineering, Gokaraju RangaRaju Institute of Engineering and Technology Hyderabad, India
}

\begin{abstract}
The purpose of the study and analyze traffic vehicular at peak hours, traffic congestion, determine level of service and provide suitable solution to reduce congestion and improve level of service. Hyderabad is a rapidly urbanizing metropolitan city with a population of 68.1lakhs. The increasing population has led to a tremendous increase in vehicular ownership resulting in high motorization rates. Vehicular population in Hyderabad is about 50lakhs. This increase in vehicular population, congestion and hazardous traffic conditions have resulted in traffic congestions, traffic delays, accidents, environ, noise pollution, air pollution and many more. Traffic volume studies are conducted for the counting number vehicles in th study area . . Data obtained from Nizampet road from the Miyapur useful for the identification of Heavy vehicular flow which studied and number of vehicle movement has studied. The data collected from surveys will be used for determination(PHO) and analysing the traffic volume, passenger car unit (PCU), congestion, Peak hour factor and Directional distribution, volume capacity ratio. A report is to be made on the road of $7 \mathrm{~km}$, semi urban road Miyapur X road to Nizampet,(Hyderabad,INDIA) is studied for vehicles count, road conditions, traffic conditions, peak hour volume, pedestrian count where congestion usually happens, manually using tally sheets and recommend some measures for increasing Level of service of the road. The semi urban road has newly grown village which is immediate vicinity to the developed area. Hence the study of This traffic vehicular moment will help the local authorities to take decisions and finally control over movement of the vehicles.
\end{abstract}

\section{Introduction:}

Vehicular movement studies will be know as traffic movement sstudies. This is also known as the traditional way to count mainly traffic movemet going on roads at a specific time. This count of vehicle for given minute, or given 60 minute in a number of vehicle particular day. There is standeard way of expressing the vehicles movement numbers.

At any study area in a given time this mode of vehicular count is called passenger car unit,(P.C.U). The number of vehicles moving in day will change from time to time. Since traffic will not uniform entire day. some times it will more and some times it very less. Especially in office timings it will be more on the roads . similarly working day of schools d colleges, business hours it will be more. Hence it is require understand vehicle movement studies for a given semi-urban developing roads for future expansion and pollution control of any developing areas..

It is essential that the traffic data should be collected ,surveyed, planned and designed the roads for the standard vehicular movement. Due to the improper planning and traffic management of the city may lead the problem for the future needs of the city. The current work studies in the city of Hyderabad at one selected priority junction. In this work we have made a report on traffic flow surveys at Nizampet Road to Miyapur X Road in Hyderabad city. The Traffic volume every time it's not constant and varies during 24 hours of the day. Daily traffic volume varies on different days of a week and different months and seasons of the year.

The word Peak hour factor (PHF) can be explained, that is equal to maximum no of vehicles in the a particular time to the maximum fifteen minutes peak movement of vehicles in the given study area.. For any T.F the PHF facot is most important parameter. Generally it states and describe by traffic engineers who are focus on PHF for estimating the capacity of the road. This factor related to signals and other critical timings of estimations canbe carried out.

\section{Literature review}

Chandra, S et.al (1995) studed about city roads on the movement vshicles and explained behaior iin the mixed flow of traffic Data obtained from the study has used in Delhi were for dynamic PCU unit for a vehicle type. It is stated that PCU for a vehicle change accordingly its own proportion in a traffic stream, data from the experiment analysed for conducting study.

\footnotetext{
* Corresponding author:vsrini51@gmail.com
} 
Satyanarayana et.al (2012) studied the effect of traffic volume, diffirentaiired speed and other relalations using PCU. Various methods for developing the PCU factors suggested by Chandra. Also observed experimented that for two wheeler vehicles the PCU value not changed in mixed traffic. Andrew, P. et.al (2005) Suggested that max flow of traffic determined with number of days which will increses the corrected volume $\mathrm{He}$ used graphical representation for the PCU.

\section{Study area}

A report is made on the road of $7 \mathrm{~km}$ stretch, Miyapur X road to Nizampet cross roads and is studied for traffic volume, road conditions, traffic conditions, peak hour volume where congestion usually happens, manually using tally sheets and recommend some measures for increasing Level of service of the road. This traffic corridor of 6 lanes is divided into two way urban road. Study is conducted on the road near Ratnadeep supermarket which is opposite to Narsingh for survey. Survey is conducted using Manual counting method with tally sheets.in Hyderabad, India

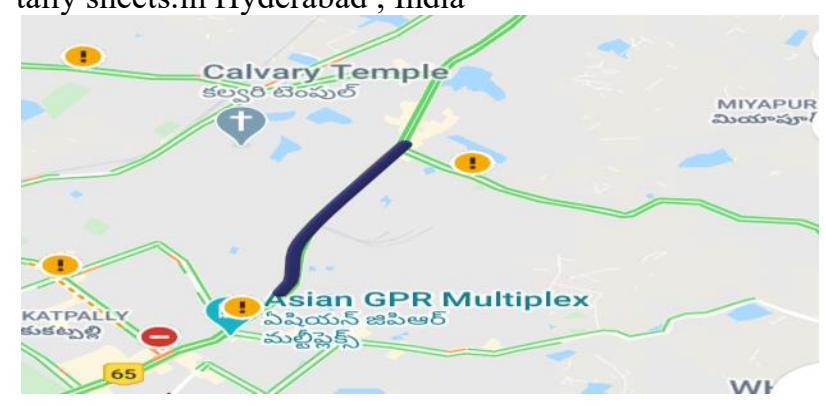

Fig. 1: study area, Miyapur X road to Nizampet cross roads, Hyderabad,India.

Majority of these buses use Nizampet to Miyapur main road for dropping school students. As a result it is leading to a one of the reasons for the traffic congestion.

There are 105-106 IT software companies in Hi-tech city which is nearer to Nizampet area. These vehicles are using the Miyapur to Nizampet main road to reach their company locality. This is also one of reason for traffic clogging on the road.

Nizampet area has population of more than 2.5lakhs. Out of which in and around $75 \%$ of the population are working professionals such IT workers and government officers and some other. All these people can see on the road during peak hours at the morning and evening as most of the companies having an opening time is 9am 0r $10 \mathrm{am}$.This is also one of the reasons for traffic congestion on the road.

Now a days we can observe every family is almost all having one car and bike and some may are having more than one too as a result of it people starts using their own vehicles for one-two members also this is leads to major traffic congestion on the road

There are 3-4 U-turns from Nizampet to Miyapur. The first turning is at the near Narsingh in Nizampet area and a head of one and half $\mathrm{km}$ we see one more U-turn likewise. As we see U-turns on the roads create major traffic congestion for incoming and outgoing vehicles on both sides of a road.

\section{Objectives}

- To check out the existing road section stability and it serviceability,

- For estimation of current trends and demands of facilities

- To report the local authority about various vehicle movements and effect on the road.

- Future development of the road require for the given V.CIvehicle count) of traffic

- $\quad$ Sustainability of the road material and their impact in the existing roads, prevent the accedents and pollution.

\section{SCOPE:}

- $\quad$ Approach road facility for the different roads

- By knowing particular road space accupied by the vehicles can planed for remaining users.

- $\quad$ Effectiveness of a traffic control measure

- To check existing, operating service condition of a roadway section.

\section{Various methods of volume studies}

Automatic Counts The observation of volume of auto presence and occupancies of road has been performed on the surface of road. within the recent year, the exploitation of latest electromagnetic spectra and wireless communication media has allowed for the traffic observation at locations above or to the side of the roadway.

\subsection{Pneumatic tubes}

In his method of traffic counting the tubes are placed at the situation or site of survey on the road surfaces. because the vehicles passes over them, compression is made within the tube., this kind of devices are used in machines which will count numbers. Some time s air compression also used in the systems that help in measure at the time when compressions exist from any vehicle counter. These are. These tubes are accurate and used worldwide for classification of auto and speed measurement for different vehicular movement.

\subsection{Video Cameras}

Iin this method cameras are installed at an elevated place so a proper view is obtained without any objections. The vehicles passing by are captured in detailed of individual vehicle and detected by video image processing system. At a same time, multiple lanes can be captured, but it require high calculation power

In this method cameras are installed at an elevated place so a proper view is obtained without any objections. The vehicles passing by are captured in detailed of individual 
vehicle and detected by video image processing system. At a same time, multiple lanes can be captured.

\subsection{Micro Mille Metre Wave Radar Detectors}

By the radar detector the radioactive signals ranging from frequencies $100 \mathrm{MHz}$ to $100 \mathrm{GHz}$ are registered by the presence of vehicles due to the reflection from the vehicle and speed depending upon signals used to be determined. Radar detectors can be used in weather conditions be op, and it will erating all the day.

\subsection{Weigh-in-Motion Sensor types}

In Different types of tracing sensors with circuits are used mst of the studies, when it is in the motion the vehicles are decided this system then special arrangement for the sensors and other equipment shud be provided

\section{Methodology}

\subsection{Preliminary Survey}

A Report is made on the road of $7 \mathrm{~km}$, Miyapur X road to Nizampet $X$ roads maximum traffic Identify the major vehicular congestions on existing road. It is a six-lane highway road and having metro railway network but still we can observe traffic congestion on road office hours, Business hours, schools and college working hours. Later, a preliminary survey was conducted to trace out the major reasons for traffic jam. The reasons are as following

\subsubsection{Dependency of schools and colleges buses on Nizampet area}

There are 11-12 schools ,2-3 junior colleges and around 2-3 engineering colleges in around Nizampet road out of which schools and colleges least 9-10 schools and colleges provide transportation facilities such as school/college buses.

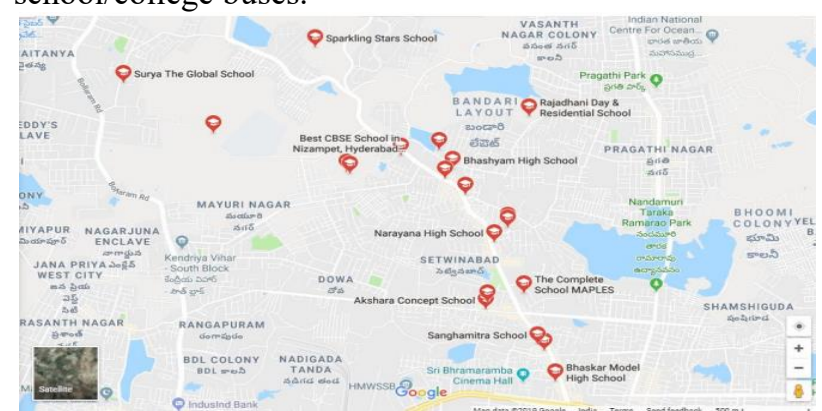

Fig. 2: map showing dependency of schools and colleges buses

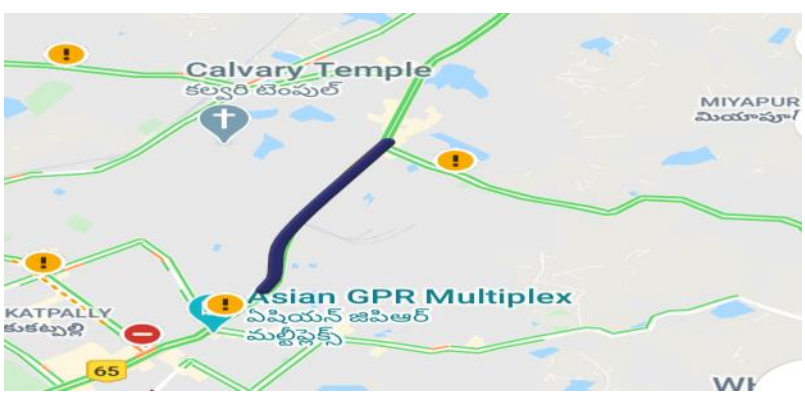

\subsubsection{Dependency of IT companies}

There are 105-106 IT software companies in Hi-tech city which is nearer to Nizampet area. Out of which some companies provide transportation facilities such as buses and company cabs.

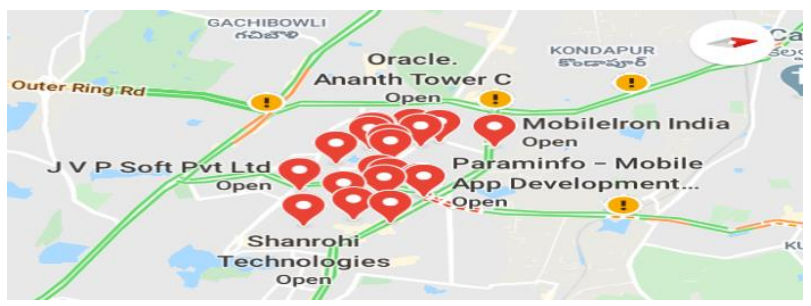

Fig. 3Map showing dependency of vehicles for IT companies

\subsubsection{More populated area:}

Nizampet area has population of more than 2.5lakhs. Out of which in most of them ar working professional related to IT professionals and government officers and General public and business people. Apart from the above. Individual vehicular ownership and Improper width at the turning of road existence also causing the traffic accumulation.

\subsection{Manual counting}

Manual counting method requires a team to collect the traffic volume data on the tally sheets. This method is employed to collect data which cannot not be collected by automatic mechanical counters, like classification of vehicles passing by, movements of vehicles at turnings and counts where the loading conditions of vehicles and number of occupants or passengers in the vehicles are to be determined. manual hours involved in talking complete counts statically sampling techniques, It is very important to observe the fluctuations of traffic volume during the day and daily variations. Then peak hours of the day are selected during which traffic is high, this is typical short count period, then the traffic volume study is made by manual counting.

There two methods of manual counting direct method and Indirect method for the count number of vehicles. Selected the direct counting $f$ the vehicular traffic with the technical team and carried out the methodology Typical counting periods, are 24hours - 1or more than 24 hours 16 hours- $6 \mathrm{am}$ to $10 \mathrm{pm}$ ( $90-95 \%$ of daily traffic) 12 hours- $7 \mathrm{am}$ to $7 \mathrm{pm}$ ( $75 \%$ of daily traffic)

Peak periods-7am to9pm and $4 \mathrm{pm}$ to $6 \mathrm{pm}$ 
Weekend- 6pm Friday-6am Monday. Exact timings are mentioned in tables respectively

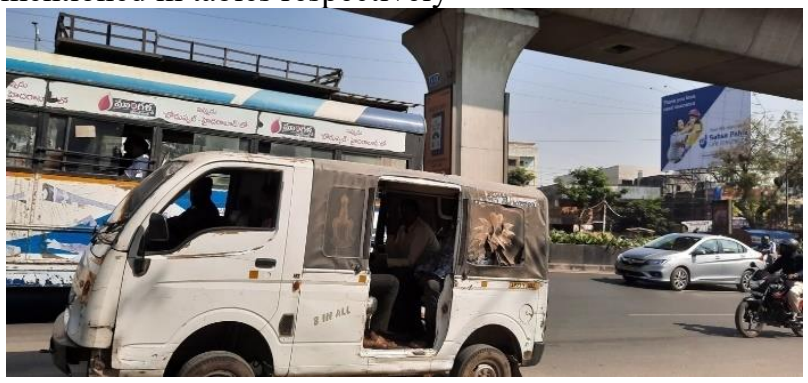

Fig. 3: Busy roads during morning peak hours

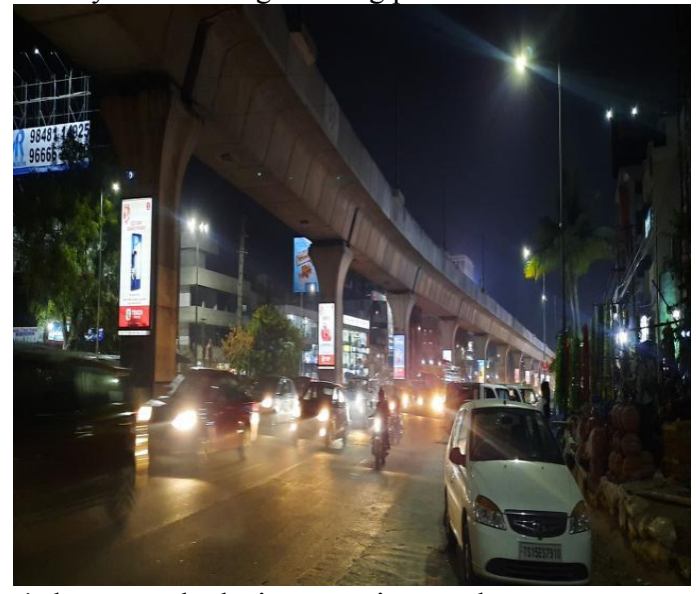

Fig. 4: busy roads during evening peak

Table1: shows data collected on 7/02/20(Monday) for traffic flow from Miyapur to Nizampet

\begin{tabular}{|l|l|l|l|l|l|}
\hline TIME & $\begin{array}{l}9: 00- \\
9: 15\end{array}$ & $\begin{array}{l}9: 15- \\
9: 30\end{array}$ & $\begin{array}{l}9: 30- \\
9: 45\end{array}$ & $\begin{array}{l}9: 45- \\
10: 00\end{array}$ & TOTAL \\
\hline $\begin{array}{l}2 \\
\text { WHEELER }\end{array}$ & 1282 & 1153 & 975 & 1023 & 4433 \\
\hline $\begin{array}{l}3 \\
\text { WHEELER }\end{array}$ & 179 & 153 & 173 & 290 & 795 \\
\hline $\begin{array}{l}4 \\
\text { WHEELER }\end{array}$ & 382 & 298 & 204 & 223 & 1107 \\
\hline BUS & 33 & 38 & 34 & 35 & 140 \\
\hline LCV & 31 & 28 & 31 & 39 & 129 \\
\hline $\begin{array}{l}\text { 2-AXILE } \\
\text { TRUCKS }\end{array}$ & 5 & 4 & 8 & 6 & 23 \\
\hline CYCLE & 0 & 0 & 1 & 0 & 1 \\
\hline
\end{tabular}

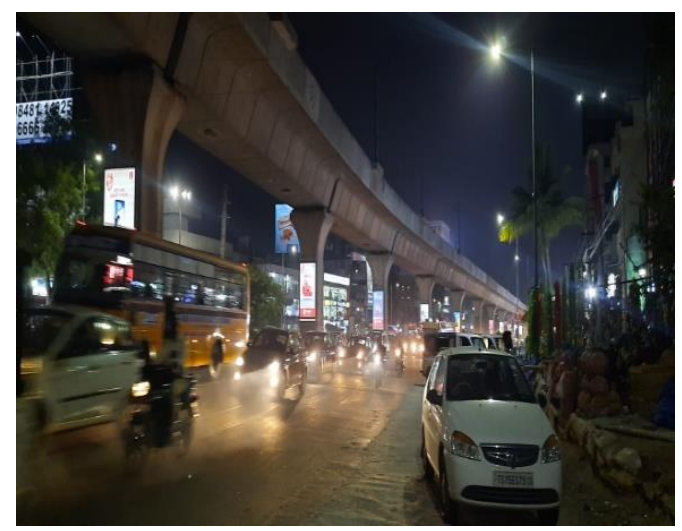

Fig. 5: busy roads during evening peak hours

\section{Traffic volume study on the field:}

Tally marks were used for noting down the number of vehicles. Going through various reports and references the peak hour considered was $6.00 \mathrm{pm}$ to $7.00 \mathrm{pm}$ and 9.00am to $10.00 \mathrm{am}$ during this peak hour vehicles were counted for every 15 minutes interval. The 15 minute interval was chosen for the calculation of peak hourly factor. After the preliminary survey the intersection was selected on the road near Ratnadeep supermarket which is opposite to Narsingh for conducting the study since it was most affected by traffic clogging during peak hours. Intially a template was designed, for entering the data on the field by surveyors with ease without much difficulty. It also helped in carrying out the study more efficiently

\section{Observations from traffic volume study:}

The following tables gives the observations made during traffic volume surveys made from $17 / 02 / 20$ to $22 / 02 / 20$ at 9:00am to $10: 00 \mathrm{am}$ and from $9 / 03 / 20$ to $14 / 03 / 20$ at 6:00pm to 7:00pm at peak hours. Surveys took place at Narshingh for road connecting Nizampet to Miyapur road and at Karchi bakery for road connecting Miyapur to Nizampet. 5 people were assigned to record the traffic count using tally sheets. Types of vehicles considered for study were 2-wheelers, 3-wheelers, 4-wheelers, buses, Low commercial vehicles (LCV), 2-axle trucks and cycles fig 3,4, 5 show the observation picture of the traffic studies during the vilume count. Table1: Total no of vehicles. Table 3,4 and 5 show day wise traffic.

\begin{tabular}{|c|c|c|c|c|c|}
\hline TIME & $\begin{array}{l}9: 00- \\
9: 15\end{array}$ & $\begin{array}{l}9: 15- \\
9: 30\end{array}$ & $\begin{array}{l}\text { 9:30- } \\
9: 45\end{array}$ & $\begin{array}{l}\text { 9:45- } \\
10: 00\end{array}$ & TOTAL \\
\hline $\begin{array}{l}2 \\
\text { WHEELER }\end{array}$ & 1282 & 1153 & 975 & 1023 & 4433 \\
\hline $\begin{array}{l}3 \\
\text { WHEELER }\end{array}$ & 179 & 153 & 173 & 290 & 795 \\
\hline $\begin{array}{l}4 \\
\text { WHEELER }\end{array}$ & 382 & 298 & 204 & 223 & 1107 \\
\hline BUS & 33 & 38 & 34 & 35 & 140 \\
\hline LCV & 31 & 28 & 31 & 39 & 129 \\
\hline $\begin{array}{l}\text { 2-AXILE } \\
\text { TRUCKS }\end{array}$ & 5 & 4 & 8 & 6 & 23 \\
\hline CYCLE & 0 & 0 & 1 & 0 & 1 \\
\hline
\end{tabular}

\begin{tabular}{|l|l|l|l|l|l|}
\hline \multicolumn{5}{|c|}{ Table4 : shows data collected on $18 / 02 / 20($ Monday) } \\
Traffic flow from Miyapurto Nizampet \\
\hline TIME & $\begin{array}{l}\mathbf{9 : 0 0} \\
\mathbf{9 : 1 5}\end{array}$ & $\begin{array}{l}\mathbf{9 : 1 5} \\
\mathbf{9 : 3 0}\end{array}$ & $\begin{array}{l}\mathbf{9 : 3 0 -} \\
\mathbf{9 : 4 5}\end{array}$ & $\begin{array}{l}\mathbf{9 : 4 5 -} \\
\mathbf{1 0 : 0 0}\end{array}$ & TOTAL \\
\hline $\begin{array}{l}2 \\
\text { WHEELER }\end{array}$ & 1046 & 975 & 1034 & 1030 & 4085 \\
\hline $\begin{array}{l}3 \\
\text { WHEELER }\end{array}$ & 130 & 135 & 159 & 141 & 565 \\
\hline $\begin{array}{l}4 \\
\text { WHEELER }\end{array}$ & 266 & 267 & 230 & 278 & 1041 \\
\hline BUS & 43 & 38 & 44 & 29 & 154 \\
\hline LCV & 37 & 46 & 40 & 37 & 160 \\
\hline
\end{tabular}




\begin{tabular}{|l|l|l|l|l|l|}
\hline $\begin{array}{l}\text { 2-AXILE } \\
\text { TRUCKS }\end{array}$ & 6 & 7 & 5 & 4 & 22 \\
\hline CYCLE & 1 & 1 & 0 & 0 & 2 \\
\hline
\end{tabular}

Similarly conducted from $17 / 02 / 20$ to $22 / 02 / 20$ every day tables created samples of one date has shown in the paper.

\subsection{Traffic Volume throughout the Week on Peak result study HOURS:}

The bar graphs given below gives variations of traffic throughout the weak from $17 / 02 / 20$ to $22 / 02 / 20$ and from $9 / 03 / 20$ to $14 / 03 / 20$ at 8.30 am to $10: 15$ am and $5: \mathrm{pm}$ to6:45pm respectively

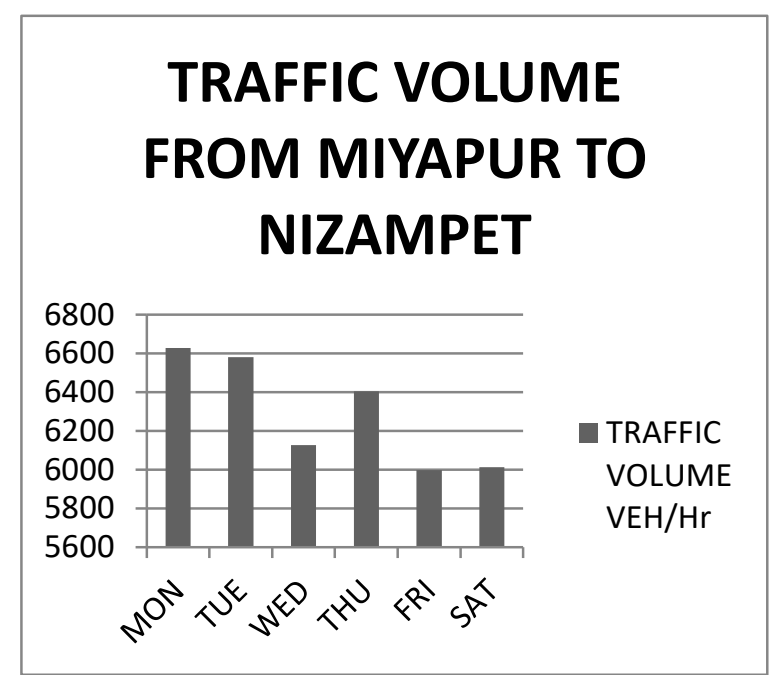

Fig. 6: Bar graph showing traffic volume for entire week for the traffic flowing from Miyapur to Nizampet ,India.during 9:00-10:00am

From the above graph, it is observed that the traffic volume for the Monday is $6628 \mathrm{veh} / \mathrm{hr}$. Whereas for Tuesday volume dropped to $6580 \mathrm{veh} / \mathrm{hr}$ not making much difference compared to Monday. As for Wednesday, the traffic volume had fallen to $6127 \mathrm{veh} / \mathrm{hr}$. For midweek that is on Thursday, volume has raised to $6404 \mathrm{veh} / \mathrm{hr}$. For the weekends as expected, it can be observed that the traffic volume has decreased to $5998 \mathrm{veh} / \mathrm{hr}$ and Similarly conducted from 17/02/20 to $22 / 02 / 20$ Every day tables created samples of one date has shown in the paper.

\section{TRAFFIC VOLUME FROM NIZAMPET TO MIYAPUR}

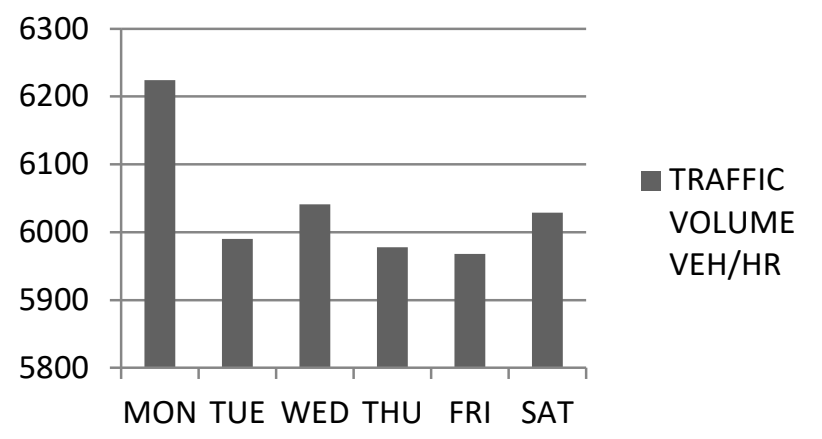

Fig. 7: Bar graph showing traffic volume for entire week for the traffic flowing from Nizampet to Miyapur India,during 9:00-10:00am

From the above graph, as we can observe traffic volume on Monday is $6215 \mathrm{veh} / \mathrm{hr}$ and $\mathrm{n}$ Tuesday traffic volume has fallen to 5990 which is quite low. On Wednesdays the volume has raised to $6041 \mathrm{veh} / \mathrm{hr}$ which is quite similar to yesterday's traffic volume. For midweek it is around $5978 \mathrm{veh} / \mathrm{hr}$. Similarly conducted from $17 / 02 / 20$ to 22/02/20 Every day tables created samples of one date has shown in the paper. Graph fig 6,7 are show for the Various days of volumes.

\section{Result}

\subsection{Guiding (Directionnel )Distribution}

Guiding distribution is nothing but percentage heavy traffic over total traffic road. It can be explained as the distribution of total vehicular volume in opposite directions during specific period of time. This is useful for analyzing roads or highways with two or more lanes in on direction. This is usefull for traffic signal designing, analyzing capacity of road etc Table 5 show the data

Table 5: Guiding distribution

\begin{tabular}{|c|c|c|c|c|c|}
\hline DAY & $\begin{array}{c}\text { Starting } \\
\text { and } \\
\text { ending } \\
\text { point of } \\
\text { road }\end{array}$ & $\begin{array}{l}\text { Cout } \\
\text { ing } \\
\text { Time }\end{array}$ & $\begin{array}{l}\text { Passeng } \\
\text { er car } \\
\text { unit } / \mathrm{hr}\end{array}$ & $\begin{array}{l}\text { Avg. } \\
\text { P.C.U }\end{array}$ & $\begin{array}{c}\text { Guiding } \\
\text { Distributi } \\
\text { on }\end{array}$ \\
\hline \multirow{4}{*}{ Monady } & \multirow[t]{2}{*}{$\begin{array}{l}\text { Miyapu } \\
\text { r to } \\
\text { nizamp } \\
\text { et }\end{array}$} & $\begin{array}{c}8: 30 \\
\text { am- } \\
10: 15 \\
\text { am }\end{array}$ & 4788 & \multirow[t]{2}{*}{$\begin{array}{c}4858 . \\
4\end{array}$} & \multirow[t]{2}{*}{52.33} \\
\hline & & $\begin{array}{c}: 00 p \\
m- \\
6: 45 p \\
m \\
\end{array}$ & 4928.2 & & \\
\hline & \multirow[t]{2}{*}{$\begin{array}{l}\text { Nizamp } \\
\text { et to } \\
\text { miyapu } \\
\text { r }\end{array}$} & $\begin{array}{c}8: 30 \\
\text { am- } \\
10: 15 \\
\text { am }\end{array}$ & 4471.9 & \multirow[t]{2}{*}{$\begin{array}{c}4424 . \\
6\end{array}$} & \multirow[t]{2}{*}{47.67} \\
\hline & & $\begin{array}{c}5: 00 p \\
m- \\
6: 45 p \\
m\end{array}$ & 4377.3 & & \\
\hline
\end{tabular}




\begin{tabular}{|c|c|c|c|c|c|}
\hline \multirow[t]{3}{*}{ Tuesday } & $\begin{array}{l}\text { Miyapu } \\
\text { r to } \\
\text { nizamp } \\
\text { et }\end{array}$ & $\begin{array}{c}8: 30 \\
\text { am- } \\
10: 15 \\
\text { am } \\
5: 00 \mathrm{p} \\
\mathrm{m}- \\
6: 45 \mathrm{p} \\
\mathrm{m}\end{array}$ & 4875 & $\begin{array}{c}4701 . \\
35\end{array}$ & 51.57 \\
\hline & \multirow[t]{2}{*}{$\begin{array}{l}\text { Nizamp } \\
\text { et to } \\
\text { miyapu } \\
\text { r }\end{array}$} & $\begin{array}{c}8: 30 \\
\text { am- } \\
10: 15 \\
\text { am }\end{array}$ & 4471.7 & \multirow[t]{2}{*}{$\begin{array}{c}4413 . \\
55\end{array}$} & \multirow[t]{2}{*}{48.43} \\
\hline & & $\begin{array}{c}5: 00 p \\
m- \\
6: 45 p \\
m\end{array}$ & 4356.1 & & \\
\hline \multirow{4}{*}{$\begin{array}{c}\text { Wednesd } \\
\text { ay }\end{array}$} & \multirow[t]{2}{*}{$\begin{array}{l}\text { Miyapu } \\
\text { r to } \\
\text { nizamp } \\
\text { et }\end{array}$} & $\begin{array}{c}8: 30 \\
\text { am- } \\
10: 15 \\
\text { am }\end{array}$ & 4606.7 & \multirow[t]{2}{*}{$\begin{array}{c}4692 . \\
8\end{array}$} & \multirow[t]{2}{*}{51.68} \\
\hline & & $\begin{array}{c}5: 00 p \\
m- \\
6: 45 p \\
m\end{array}$ & 4778.9 & & \\
\hline & \multirow[t]{2}{*}{$\begin{array}{l}\text { Nizamp } \\
\text { et to } \\
\text { miyapu } \\
\text { r }\end{array}$} & $\begin{array}{c}8: 30 \\
\text { am- } \\
10: 15 \\
\text { am }\end{array}$ & 4563.9 & \multirow[t]{2}{*}{$\begin{array}{c}4386 . \\
15\end{array}$} & \multirow[t]{2}{*}{48.32} \\
\hline & & $\begin{array}{c}5: 00 p \\
m- \\
6: 45 p \\
m\end{array}$ & 4208.5 & & \\
\hline \multirow[t]{4}{*}{ Thursday } & \multirow[t]{2}{*}{$\begin{array}{l}\text { Miyapu } \\
\text { r to } \\
\text { nizamp } \\
\text { et }\end{array}$} & $\begin{array}{c}8: 30 \\
\text { am- } \\
10: 15 \\
\text { am }\end{array}$ & 4459.8 & \multirow[t]{2}{*}{$\begin{array}{c}4736 . \\
2\end{array}$} & \multirow[t]{2}{*}{51.07} \\
\hline & & $\begin{array}{c}5: 00 p \\
m- \\
6: 45 p \\
m\end{array}$ & 4873.4 & & \\
\hline & \multirow[t]{2}{*}{$\begin{array}{l}\text { Nizamp } \\
\text { et to } \\
\text { miyapu } \\
\text { r }\end{array}$} & $\begin{array}{l}8: 30 \\
\text { am-- } \\
8: 30 \\
\text { am- }\end{array}$ & 4459.8 & \multirow[t]{2}{*}{$\begin{array}{c}4535 . \\
95\end{array}$} & \multirow[t]{2}{*}{48.93} \\
\hline & & $\begin{array}{c}5: 00 p \\
m- \\
6: 45 p \\
m\end{array}$ & 4620.1 & & \\
\hline \multirow{5}{*}{ Friday } & \multirow[t]{2}{*}{$\begin{array}{l}\text { Miyapu } \\
\text { r to } \\
\text { nizamp } \\
\text { et }\end{array}$} & $\begin{array}{c}8: 30 \\
\text { am- } \\
10: 15 \\
\text { am }\end{array}$ & 4700.5 & \multirow[t]{2}{*}{$\begin{array}{c}4978 . \\
25\end{array}$} & \multirow[t]{2}{*}{52.1} \\
\hline & & $\begin{array}{c}5: 00 p \\
m- \\
6: 45 p \\
m\end{array}$ & 5256 & & \\
\hline & \multirow[t]{2}{*}{$\begin{array}{l}\text { Nizamp } \\
\text { et to } \\
\text { miyapu } \\
\text { r }\end{array}$} & $\begin{array}{c}8: 30 \\
\text { am- } \\
10: 15 \\
\text { am }\end{array}$ & 4708.7 & \multirow[t]{2}{*}{$\begin{array}{c}4561 . \\
5\end{array}$} & \multirow[t]{2}{*}{47.90} \\
\hline & & $\begin{array}{c}5: 00 p \\
m- \\
6: 45 p \\
m\end{array}$ & 4414.3 & & \\
\hline & $\begin{array}{l}\text { Miyapu } \\
\text { r to } \\
\text { nizamp } \\
\text { et }\end{array}$ & $\begin{array}{c}8: 30 \\
\text { am- } \\
10: 15 \\
\text { am }\end{array}$ & 4433.8 & $\begin{array}{c}4599 . \\
55\end{array}$ & 50.9 \\
\hline
\end{tabular}

\begin{tabular}{|c|c|c|c|c|c|}
\hline \multirow[t]{3}{*}{ Saturday } & & $\begin{array}{c}5: 00 p \\
m- \\
6: 45 p \\
m\end{array}$ & 5165.3 & & \\
\hline & \multirow[t]{2}{*}{$\begin{array}{l}\text { Nizamp } \\
\text { et to } \\
\text { miyapu } \\
\quad \mathrm{r}\end{array}$} & $\begin{array}{c}8: 30 \\
\text { am- } \\
10: 15 \\
\text { am }\end{array}$ & 4590.9 & \multirow[t]{2}{*}{$\begin{array}{c}4747 . \\
45\end{array}$} & \multirow[t]{2}{*}{49.1} \\
\hline & & $\begin{array}{c}5: 00 p \\
m- \\
6: 45 p \\
m\end{array}$ & 4704 & & \\
\hline
\end{tabular}

From the above table 4 we can observe that around 51\% to $53 \%$ vehicles travel from Miyapur to Nizampet and around $47 \%$ to $49.5 \%$ are travelling in the direction from Nizampet to Miyapur. Both in the morning and evenings there remains the same kind of traffic during rush hours .So not much variation is observed. There are to Miyapur go to Gachibowli. During Saturdays it is observed that the difference many IT firms and companies in Gachibowli, Inida. So major traffic observed in the direction Nizampet in directional distribution is not more.

\subsection{Vehicular Composition}

Vehicular composition is given in form of percentages so it is easy to understand the type of vehicle most used for transporting. It gives an idea about public transportations during the week during peak hours

From the above pie diagram, we can conclude that 2wheelers occupy the major portion and is playing a big role with63.951\% and 4-wheeler occupy the 2nd major portion with $20.537 \%$. 3-wheelers ie auto occupy $9.321 \%$ of total vehicle population. Buses, LCV, 2-Axle are in very low population with percentages of $2.264 \%$, $2.314 \%$ and $0.39 \%$ respectively. There are very few school buses moving during 9:00am to 10:00am. Majority of bus are public transport buses. It is also observed that majority of 2-axle trucks are water tankers. Fig 8 and 9 shown the information about the different vehicles inn the peak hour similarly . it is don for thd all days from $17 / 02 / 20$ to $22 / 02 / 20$ Every day tables created samples of one date has shown in the paper

\begin{tabular}{|c|c|c|c|}
\hline \multicolumn{4}{|c|}{ Table 6: Total no of vehicles Trafiic data } \\
\hline \multicolumn{4}{|c|}{ Table sowing the total number of vehicles } \\
\hline DATE & TIME & DIRECTION & $\begin{array}{c}\text { NO OF } \\
\text { VEHICLES }\end{array}$ \\
\hline \multirow[t]{2}{*}{$17 / 02 / 20$} & \multirow[t]{2}{*}{$\begin{array}{l}\text { 9:00am- } \\
\text { 10:00:am }\end{array}$} & $\begin{array}{l}\text { MIYAPUR TO } \\
\text { NIZAMPET }\end{array}$ & 6628 \\
\hline & & $\begin{array}{l}\text { NIZAMPET TO } \\
\text { MIYAPUR }\end{array}$ & 6215 \\
\hline \multirow[t]{2}{*}{$18 / 02 / 20$} & \multirow[t]{2}{*}{$\begin{array}{l}\text { 9:00am- } \\
\text { 10:00:am }\end{array}$} & $\begin{array}{l}\text { MIYAPUR TO } \\
\text { NIZAMPET }\end{array}$ & 6580 \\
\hline & & $\begin{array}{l}\text { NIZAMPET TO } \\
\text { MIYAPUR }\end{array}$ & 5990 \\
\hline \multirow[t]{2}{*}{$19 / 02 / 20$} & \multirow[t]{2}{*}{$\begin{array}{c}8-45 \mathrm{~m}- \\
10: 00: \mathrm{am}\end{array}$} & $\begin{array}{l}\text { MIYAPUR TO } \\
\text { NIZAMPET }\end{array}$ & 6127 \\
\hline & & $\begin{array}{l}\text { NIZAMPET TO } \\
\text { MIYAPUR }\end{array}$ & 6041 \\
\hline \multirow[t]{2}{*}{$20 / 02 / 20$} & \multirow[t]{2}{*}{$\begin{array}{c}\text { 9:00am- } \\
\text { 10:00:am }\end{array}$} & $\begin{array}{l}\text { MIYAPUR TO } \\
\text { NIZAMPET }\end{array}$ & 6406 \\
\hline & & $\begin{array}{c}\text { NIZAMPET TO } \\
\text { MIYAPUR }\end{array}$ & 5978 \\
\hline
\end{tabular}




\begin{tabular}{|c|c|c|c|}
\hline \multirow[t]{2}{*}{$21 / 02 / 20$} & \multirow[t]{2}{*}{$\begin{array}{l}\text { 9:00am- } \\
\text { 10:00:am }\end{array}$} & $\begin{array}{l}\text { MIYAPUR TO } \\
\text { NIZAMPET }\end{array}$ & 5998 \\
\hline & & $\begin{array}{l}\text { NIZAMPET TO } \\
\text { MIYAPUR }\end{array}$ & 5938 \\
\hline \multirow[t]{2}{*}{$22 / 02 / 20$} & \multirow[t]{2}{*}{$\begin{array}{l}\text { 9:00am- } \\
\text { 10:00:am }\end{array}$} & $\begin{array}{l}\text { MIYAPUR TO } \\
\text { NIZAMPET }\end{array}$ & 6013 \\
\hline & & $\begin{array}{l}\text { NIZAMPET TO } \\
\text { MIYAPUR }\end{array}$ & 6025 \\
\hline \multirow[t]{2}{*}{$9 / 03 / 20$} & \multirow[t]{2}{*}{$\begin{array}{l}\text { 6:00pm- } \\
7: 00 \mathrm{pm}\end{array}$} & $\begin{array}{c}\text { MIYAPUR TO } \\
\text { NIZAMPET }\end{array}$ & 6510 \\
\hline & & $\begin{array}{l}\text { NIZAMPET TO } \\
\text { MIYAPUR }\end{array}$ & 5653 \\
\hline \multirow[t]{2}{*}{$10 / 03 / 20$} & \multirow[t]{2}{*}{$\begin{array}{l}\text { 6:00pm- } \\
7: 00 \mathrm{pm}\end{array}$} & $\begin{array}{l}\text { MIYAPUR TO } \\
\text { NIZAMPET }\end{array}$ & 6425 \\
\hline & & $\begin{array}{c}\text { NIZAMPET TO } \\
\text { MIYAPUR }\end{array}$ & 5473 \\
\hline \multirow[t]{2}{*}{$11 / 03 / 20$} & \multirow[t]{2}{*}{$\begin{array}{l}\text { 6:00pm- } \\
7: 00 \mathrm{pm}\end{array}$} & $\begin{array}{l}\text { MIYAPUR TO } \\
\text { NIZAMPET }\end{array}$ & 6220 \\
\hline & & $\begin{array}{c}\text { NIZAMPET TO } \\
\text { MIYAPUR }\end{array}$ & 5342 \\
\hline \multirow[t]{2}{*}{$12 / 03 / 20$} & \multirow[t]{2}{*}{$\begin{array}{l}\text { 6:00pm- } \\
7: 00 \mathrm{pm}\end{array}$} & $\begin{array}{l}\text { MIYAPUR TO } \\
\text { NIZAMPET }\end{array}$ & 6338 \\
\hline & & $\begin{array}{l}\text { NIZAMPET TO } \\
\text { MIYAPUR }\end{array}$ & 5676 \\
\hline \multirow[t]{2}{*}{$13 / 03 / 20$} & \multirow[t]{2}{*}{$\begin{array}{l}\text { 6:00pm- } \\
\text { 7:00pm }\end{array}$} & $\begin{array}{l}\text { MIYAPUR TO } \\
\text { NIZAMPET }\end{array}$ & 6673 \\
\hline & & $\begin{array}{c}\text { NIZAMPET TO } \\
\text { MIYAPUR }\end{array}$ & 5461 \\
\hline \multirow[t]{2}{*}{$14 / 03 / 20$} & \multirow[t]{2}{*}{$\begin{array}{l}\text { 6:00pm- } \\
7: 00 \mathrm{pm}\end{array}$} & $\begin{array}{l}\text { MIYAPUR TO } \\
\text { NIZAMPET }\end{array}$ & 6745 \\
\hline & & $\begin{array}{c}\text { NIZAMPET TO } \\
\text { MIYAPUR }\end{array}$ & 5807 \\
\hline
\end{tabular}

\subsection{Types of vehicles during peak hours on Tuesday}

\section{VEHICULAR COMPOSITION IN \%}

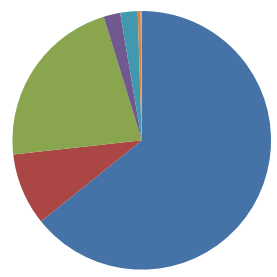

\section{2-WHEELER
3-WHEELER \\ 4-WHEELER \\ BUS}

\section{VEHICULAR COMPOSITION IN \%}

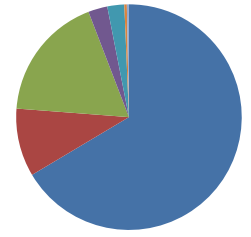

-2-WHEELER

3-WHEELER

4-WHEELER

BUS

Fig. 9 vehicular composition during peak hours on Thursday

The paper From the above pie chart, 2-wheeler occupy the most of the composition with highest percentage of 66.672. We can deduce that people mainly depend on 2wheelers. Next vehicle with most dependency is 4wheelers with $17.99 \%$ as there are many IT firms

\section{Conclusion}

The above survey has been conducted and studied for traffic in Miyapur to Nizampet (Hyderabad, India) has the following are the conclusion drawn from the study.

- While analyzing for steam composition flow it is observed that the percentage of volume of 2wheelers are around $62-65 \%$ of total volume of vehicles. The major source of 2-wheelers are local residents located around this area. It is also observed that the volume of private vehicles compared to public vehicles in this route is inadequate.

- $\quad$ For peak hour factor (PHF) the average PHF is about 0.943 for traffic flow towards Nizampet in the morning peak hours and highest PHF during the whole week is for the same is 0.970 . Similarly average PHF for the traffic flow towards Miyapur is 0.963 in the morning and highest PHF for the entire week is 0.981 for the same. In the evenings the average PHFs are 0.964 and 0.947 for traffic flow towards Nizampet and Miyapur respectively. The highest PHFs for the entire week are 0.971 and 0.974 for traffic flow towards Miyapur and Nizampet respectively. From the above observations, we can see that the PHF for the entire during morning and evening are around 0.97 which is greater than 0.95 which indicates heavy traffic during peak hours.

- From the volume tables is seen that the traffic flow towards Nizampet on Friday evenings and Saturdays evenings are very high compared to other days. deduce that people mainly depend on 2 -wheelers. Next vehicle with most dependency is 4-wheelers with $21.8735 \%$ as there are many IT firms. 3-wheelers occupy about $8.984 \%$. Frequency of buses is low and is about $2.068 \%$. LCVs occupy about $20164 \%$ and least occupancies are 2 -axle trucks and cycles with $0.37 \%$ ans $0.12 \%$ respectively
Fig. 8 : vehicular composition during peak hours on

Tuesday

From the above pie chart, 2-wheeler occupy most of the composition with highest percentage of 63.859 . We can 
2. Abhishek,et.al, 2018 "Traffic volume measurements of Pune University Road to Paud Phata" IRJE and Technologies, e-ISSN2395-0056.

3. Ahmed Al. Kaishy et.al Jung and Hesham Rakha. (2005), "Developing Passenger Car Equivalency Factor for Heavy Vehicles during Congestion". JTE, ASCE, Vol. 131, No. 7, pp. 514-523.

4. Chandra, S. et.al, P.K. (2000), "Factors Affecting PCU in Mixed Traffic Situations in Urban Roads", Road Transport Research, Vol. 9, No. 3, Australian Road Research Board, pp. 40- 50.

5. Chandra S., Kumar, et.al (1995), "Dynamic PCU and Estimation of Capacity of Urban Roads", Indian Highways, IRC, Vol. 23, No. 4, pp. $17-28$.

6. Maitra, B., et.al. (1999). "Modelling Congestion on Urban Roads and Assessing Level of Service". Journal of T.E, ASCE, Vol.125, No.6, 08-514.

7. Marwah, et.al. (2000). "Level of service classification for urban heterogeneous traffic: A case study of Kanpur etropolis.": 4th Int. Symp Highway Capacity, Maui, Hawaii, 271-286.

8. Satyanarayana PVH, et.al, "Development of PCU factors and capacity norms at mid blocks of rural highways in Visakhapatnam", Indian J. Edu. Inf. Manage.,Vol. 1, No.5(May2012), ISSN 22775374, pp.197-202

9. V. T Hamizh et.al, "Study of the Effect of Traffic Volume and Road Width on PCU Value of Vehicles using Microscopic Simulation", Paper no: 542, IRC, pp.133-149.

10. Birva B. Shah, Prof. N. G. Raval, "Estimation of Capacity for Arterial Road of Urban Area", jour. IJIRT, 2016, 63-64. 